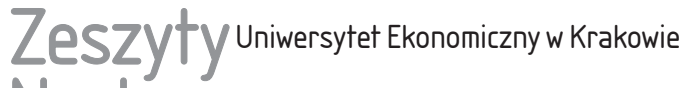 Naukowe
}

\section{Ocena wdrożenia procedur raportowania schematów podatkowych na przykładzie wybranych przedsiębiorstw}

\section{Streszczenie}

Cel: Celem artykułu jest ocena wdrożenia procedur raportowania schematów podatkowych na podstawie wybranych spółek.

Metodyka badań: W artykule zastosowano następujące metody badawcze: analizę aktów prawnych, literatury przedmiotu oraz studium przypadku.

Wyniki badań: Z przeprowadzonych badań wynika, że wdrożenie procedur raportowania schematów podatkowych miało zarówno zalety, jak i wady. Do głównych zalet wdrożenia procedur raportowania schematów podatkowych można zaliczyć umożliwienie efektywniejszego zarządzania ryzykiem podatkowym. Największą wadą wdrożenia raportowania schematów podatkowych było zaś to, że we wszystkich badanych podmiotach zarząd i kierownicy działów finansowo-księgowych mieli problemy ze zrozumieniem terminów używanych w Ordynacji podatkowej, związanych ze schematami podatkowymi.

Wnioski: Z przeprowadzonych badań wynika, że efektywne wdrożenie procedur raportowania schematów podatkowych umożliwia skuteczniejsze zarządzanie ryzykiem podatkowym. Konieczne są dalsze badania, z których będzie jednoznacznie wynikać, że dzięki

Maciej Leszek Hyży, Uniwersytet Gdański, Wydział Zarządzania, Katedra Rachunkowości, ul. Armii Krajowej 101, 81-824 Sopot, e-mail: maciej.hyzy@ug.edu.pl, ORCID: https://orcid. org/0000-0002-5810-0819.

Artykuł udostępniany na licencji Creative Commons Uznanie autorstwa-Użycie niekomercyjne-Bez utworów zależnych 4.0 (CC BY-NC-ND 4.0); https://creativecommons.org/licenses/ by-nc-nd/4.0/ 
wdrożeniu procedur raportowania schematów podatkowych zmaleje ryzyko popełnienia błędu podczas raportowania schematów podatkowych.

Wkład w rozwój dyscypliny: Oryginalnym wkładem artykułu jest prezentacja wraz z charakterystyką elementów procedury raportowania schematów podatkowych.

Słowa kluczowe: schematy podatkowe, MDR, procedury raportowania schematów podatkowych, opodatkowanie.

Klasyfikacja JEL: M41.

\section{Wprowadzenie}

Procedury raportowania schematów podatkowych pomagają ograniczyć ryzyko podatkowe. Celem artykułu jest ocena wdrożenia procedur raportowania schematów podatkowych na podstawie wybranych spółek. Tezę badawczą pracy sformułowano następująco: „Dzięki wdrożeniu procedur raportowania schematów podatkowych codzienne funkcjonowanie wybranych przedsiębiorstw jest efektywniejsze, a przede wszystkim umożliwia skuteczne zarządzanie ryzykiem podatkowym". Analizując wskazane korzyści, zastosowano następujące metody badawcze: analizę aktów prawnych, literatury przedmiotu oraz studium przypadku. W studium przypadku zaprezentowano wdrożenie procedur raportowania schematów podatkowych na przykładzie trzech podmiotów. Badania przeprowadzono w latach 2019-2020.

W artykule zaprezentowano również zalety i wady wdrożenia procedur raportowania schematów podatkowych na podstawie wdrożeń dokonanych w trzech wybranych spółkach prawa handlowego. W podsumowaniu wskazano dalsze możliwe kierunki badań nad funkcjonowaniem i udoskonaleniem raportowania schematów podatkowych.

\section{Wprowadzenie do raportowania schematów podatkowych}

Uregulowania dotyczące raportowania schematów podatkowych (mandatory disclosure rules - MDR) są nowymi przepisami w polskim ustawodawstwie podatkowym. Zaczęły one obowiązywać od 1 stycznia 2019 r. w wyniku nowelizacji Ordynacji podatkowej (Obowiqzek... 2019). Celem wprowadzenia tych regulacji jest uszczelnienie systemu podatkowego.

Zgodnie z art. 86a pkt 10 ustawy Ordynacja podatkowa (Ustawa z dnia 29 sierpnia 1997 r. ... 2019), przez schemat podatkowy rozumie się uzgodnienie, które:

a) spełnia kryterium głównej korzyści oraz posiada ogólną cechę rozpoznawczą, 
b) posiada szczególną cechę rozpoznawczą,

c) posiada inną szczególną cechę rozpoznawczą.

Obowiązek raportowania schematów podatkowych został nałożony na trzy rodzaje podmiotów: promotora, korzystającego i wspomagającego. W praktyce promotorami są przede wszystkim doradcy podatkowi, radcy prawni, adwokaci, pracownicy banku lub instytucji finansowej doradzającej klientom oraz w określonych sytuacjach biegły rewident (Kaczmarek 2019, s. 296). Biegły rewident staje się promotorem w sytuacji, gdy doradzi swojemu klientowi, jak zmniejszyć obciążenia podatkowe. Korzystającym jest firma, która zastosowała się do podpowiedzi doradców podatkowych, radców prawnych, adwokatów czy biegłych rewidentów i zamierza wdrożyć zaproponowany przez wymienione osoby schemat podatkowy. Wspomagający to podmiot, który pomaga w opracowaniu, rozpowszechnianiu lub wdrażaniu uzgodnienia, np. przez wykonanie zlecenia doradczego, księgowego, konsultingowego, dotyczącego schematu podatkowego. Przykładem może być biuro rachunkowe, któremu promotor lub korzystający zlecił przygotowanie analizy wykazującej różnice w przepływach finansowych, zachodzące między stanem sprzed wdrożenia schematu podatkowego oraz po jego wdrożeniu (Kaczmarek 2019, s. 298).

Zgodnie z przepisami Ordynacji podatkowej schematy podatkowe dzielą się na: transgraniczne, standaryzowane i inne. Raportowaniu podlegają wszystkie schematy podatkowe transgraniczne, a pozostałe tylko wówczas, gdy spełnione jest jedno z następujących tzw. kryteriów kwalifikowanego korzystającego (Ustawa z dnia 29 sierpnia 1997 r. ... 2019, art. 86a par. 4), tzn.:

- przychody lub koszty korzystającego albo wartość aktywów tego podmiotu w rozumieniu przepisów o rachunkowości, ustalone na podstawie prowadzonych ksiąg rachunkowych, przekroczyły w roku poprzedzającym lub w bieżącym roku obrotowym równowartość 10000000 euro,

- jeżeli udostępniane lub wdrażane uzgodnienie dotyczy rzeczy lub praw o wartości rynkowej przekraczającej równowartość 2500000 euro,

- jeżeli korzystający jest podmiotem powiązanym w rozumieniu art. $23 \mathrm{~m}$ ust. 1 pkt 4 Ustawy z dnia 26 lipca 1991 r. o podatku dochodowym od osób fizycznych lub art. 11a ust. 1 pkt 4 Ustawy z dnia 15 lutego 1992 r. o podatku dochodowym od osób prawnych z takim podmiotem.

W przypadku schematów podatkowych szczególnego znaczenia nabiera właściwe administrowanie procesem zarządzania schematami podatkowymi. Bardzo pomocna w tym zakresie jest konieczność posiadania wewnętrznej procedury dotyczącej raportowania schematów podatkowych.

Z przepisów Ordynacji podatkowej wynika, że osoby prawne oraz jednostki organizacyjne nieposiadające osobowości prawnej będące promotorami, zatrudniające promotorów lub faktycznie wypłacające im wynagrodzenie, których przy- 
chody lub koszty, w rozumieniu przepisów o rachunkowości, ustalone na podstawie prowadzonych ksiąg rachunkowych, przekroczyły w roku poprzedzającym rok obrotowy równowartość 8000000 zł, muszą wprowadzić i zastosować wewnętrzną procedurę w zakresie przeciwdziałania niewywiązywaniu się z obowiązku przekazywania informacji o schematach podatkowych, zwaną dalej „wewnętrzną procedurą" (Ustawa z dnia 29 sierpnia 1997 r. ... 2019, art. 861 par. 1).

\section{Przegląd aktów prawnych w zakresie raportowania schematów podatkowych}

Wprowadzenie przepisów dotyczących raportowania schematów podatkowych wynikało z częściowej transpozycji Dyrektywy Rady (UE) 2018/8221 z dnia 25 maja 2018 r. zmieniającej dyrektywę 2011/16/UE w zakresie obowiązkowej automatycznej wymiany informacji w dziedzinie opodatkowania w odniesieniu do podlegających zgłoszeniu uzgodnień transgranicznych.

Według stanu na 31 lipca 2019 r. obowiązek raportowania schematów podatkowych funkcjonuje w następujących państwach: Węgry, Litwa, Polska i Słowenia. Wstępna wersja raportowania schematów podatkowych została opublikowana w 14 państwach UE: Austria, Cypr, Czechy, Dania, Estonia, Finlandia, Niemcy, Włochy, Luksemburg, Niderlandy, Portugalia, Słowacja, Hiszpania i Wielka Brytania. W pozostałych państwach członkowskich UE trwają formalne (Łotwa i Szwecja) bądź nieformalne (Belgia, Francja, Rumunia, Irlandia i Malta) konsultacje w zakresie wdrożenia przepisów dotyczących raportowania schematów podatkowych. Pozostałe trzy kraje członkowskie (Bułgaria, Chorwacja i Grecja) nie podjęły działań legislacyjnych w zakresie wdrożenia raportowania schematów podatkowych (EU Mandatory... 2019).

W przypadku Polski obowiązek raportowania schematów podatkowych wszedł w życie 1 stycznia 2019 r. Do Ustawy z dnia 29 sierpnia 1997 r. - Ordynacja podatkowa (publikacja: Dz.U. z 2019 r. poz. 900 z późn. zm.) został dodany rozdział 11a zatytułowany „Informacje o schematach podatkowych”.

Podkreślić należy, że regulacje krajowe różnią się fundamentalnie w dwóch aspektach od przepisów unijnych. Po pierwsze, zakresem krajowego raportowania są objęte nie tylko schematy podatkowe transgraniczne, ale także krajowe. Po drugie, celem dyrektywy jest przeciwdziałanie unikaniu opodatkowania, które jest zjawiskiem szkodliwym, naruszającym zasady uczciwej konkurencji na wspólnym rynku, natomiast Ministerstwo Finansów za schematy podatkowe uznaje także m.in. zupełnie legalne i dozwolone przez ustawodawcę rozwiązania przynoszące korzyści podatkowe (np. działalność w SSE, pod pewnymi warunkami możliwość korzystania z ulgi B+R i Innovation Box). Powoduje to de facto 
nałożenie dodatkowych obowiązków administracyjnych na przedsiębiorców, którzy nie mają nic wspólnego z unikaniem opodatkowania ani w wymiarze krajowym, ani zagranicznym.

Wprowadzając schematy podatkowe do polskiego systemu podatkowego, ustawodawca znacznie rozszerzył zakres czynności traktowanych jako schematy podatkowe. $\mathrm{Z}$ powodu nieprawidłowej transpozycji kryterium głównej korzyści oraz kryterium transgranicznego nie został spełniony minimalny standard harmonizacji (Ladziński i Wasiluk 2019).

Obowiązek przekazywania informacji o schematach podatkowych ciąży przede wszystkim na promotorze, ale w pewnych okolicznościach, wymienionych w przepisach Ordynacji podatkowej, również na korzystającym i wspomagającym.

Promotor przekazuje Szefowi Krajowej Administracji Skarbowej informację o schemacie podatkowym na formularzu MDR-1, w terminie 30 dni od dnia następnego po udostępnieniu schematu podatkowego, od następnego dnia po przygotowaniu do wdrożenia schematu podatkowego lub od dnia dokonania pierwszej czynności związanej z wdrażaniem schematu podatkowego - w zależności od tego, które z tych zdarzeń nastąpi wcześniej.

Jeżeli korzystający nie został poinformowany zgodnie z art. 86b par. 2 lub 3 Ordynacji podatkowej, przekazuje Szefowi Krajowej Administracji Skarbowej informację o schemacie podatkowym na formularzu MDR-1, w terminie $30 \mathrm{dni}$ od dnia następującego po udostępnieniu mu schematu podatkowego, przygotowaniu przez niego schematu podatkowego do wdrożenia lub od dnia dokonania pierwszej czynności związanej z wdrażaniem schematu podatkowego przez korzystającego, w zależności od tego, które z tych zdarzeń nastąpi wcześniej (Ustawa z dnia 29 sierpnia 1997 r. ... 2019, art. 86b).

Jeżeli wspomagający: 1) nie został poinformowany o NSP schematu podatkowego lub nie została mu przekazana informacja, o której mowa w art. 86b par. 3 Ordynacji podatkowej oraz 2) przy zachowaniu staranności ogólnie wymaganej w dokonywanych przez niego czynnościach, przy uwzględnieniu zawodowego charakteru jego działalności, obszaru jego specjalizacji oraz przedmiotu wykonywanych przez niego czynności, powziął lub powinien był powziąć wątpliwości, że uzgodnienie, w odniesieniu do którego jest wspomagającym, może stanowić schemat podatkowy - jest on obowiązany niezwłocznie, nie później jednak niż w terminie pięciu dni roboczych od dnia, w którym powziął lub powinien był powziąć wątpliwości, o których mowa w pkt 2, wystąpić z odrębnym pismem do promotora lub korzystającego zlecających wykonanie czynności o przekazanie mu pisemnego oświadczenia, że uzgodnienie nie stanowi schematu podatkowego.

W terminie, o którym mowa w zdaniu poprzednim, wspomagający obowiązany jest zawiadomić Szefa Krajowej Administracji Skarbowej o wystąpieniu sytuacji opisanej powyżej, wskazując dzień, w którym powziął on wątpliwości, że uzgod- 
nienie stanowi schemat podatkowy, oraz liczbę podmiotów, do których wystąpił o przekazanie mu pisemnego oświadczenia, że uzgodnienie nie stanowi schematu podatkowego. Wspomagający może wstrzymać się z wykonaniem czynności w odniesieniu do uzgodnienia do dnia otrzymania tego oświadczenia, potwierdzenia nadania numeru schematu podatkowego (NSP) lub informacji, o której mowa w art. 86b par. 3 Ordynacji podatkowej (Ustawa z dnia 29 sierpnia 1997 r... 2019, art. 86b par. 3).

Ustawodawca określił również datę graniczną dla:

- schematu podatkowego transgranicznego: 25 czerwca 2018 r.,

- schematu innego niż schemat podatkowy transgraniczny: 1 listopada $2018 \mathrm{r}$.

Wymienione daty graniczne oznaczają konieczność retrospektywnego przekazywania informacji o schemacie podatkowym, jeśli pierwszej jego czynności związanej z jego wdrożeniem dokonano po dacie granicznej (Objaśnienia podatkowe... 2019).

O szybkim i niedbałym wdrożeniu przepisów o raportowaniu schematów podatkowych świadczy fakt, że promotorzy, korzystający i w określonych sytuacjach wspomagający będą musieli ponownie zgłosić informacje o schematach podatkowych. Jest to wynik tego, że Polska jako jedyny kraj w Unii Europejskiej wprowadziła obowiązek raportowania transakcji krajowych, podczas gdy według uregulowań unijnych obowiązek raportowania dotyczy tylko transakcji transgranicznych (Zalewski 2020, Modzelewski 2019).

Zgodnie z przygotowywaną nowelizacją przepisów o schematach podatkowych, przewidzianą na gruncie nowych przepisów, ma zostać wprowadzone nałożenie obowiązku ponownego zaraportowania schematów podatkowych transgranicznych, jeśli pierwszej czynności związanej z ich wdrażaniem dokonano między 26 czerwca 2018 r. a 31 marca 2020 r. Zgodnie z nowymi przepisami raportowanie powinno następować według podobnej metodologii jak na gruncie obecnych przepisów:

- w pierwszej kolejności schemat powinien zaraportować promotor (w terminie do 31 maja 2020 r.);

- jeśli korzystający nie został poinformowany o NSP schematu, raportuje schemat w terminie do 30 lipca 2020 r.; termin ten odnosi się zarówno do informacji o schemacie podatkowym (MDR-1), jak i informacji o korzystaniu ze schematu (MDR-3);

- w dalszej kolejności obowiązek zaraportowania schematu transgranicznego może ciążyć również na wspomagającym, jeśli nie został on poinformowany o NSP schematu (termin na złożenie informacji upływa 31 sierpnia 2020 r.) - nałożenie retrospektywnego obowiązku raportowania schematów na wspomagającego jest nowym rozwiązaniem, które nie występowało na gruncie poprzedniej ustawy. 
Nowy projekt ustawy przewiduje również uproszczone zasady przekazywania informacji o wspomnianych wyżej schematach transgranicznych - obowiązek ponownego zaraportowania schematu będzie zasadniczo ciążył na podmiocie, który uprzednio przekazał tę informację do Szefa Krajowej Administracji Skarbowej (dotyczy to sytuacji, gdy do przekazania informacji o schemacie zobowiązany był więcej niż jeden podmiot). Zgodnie z projektowanymi zmianami dotychczas nadane NSP dla schematów transgranicznych staną się nieważne z mocy prawa z dniem 1 kwietnia 2020 r. i zostaną zastąpione przez nowe NSP nadane ponownie zgłoszonym schematom transgranicznym (które będą zgodne z wzorcem wymaganym przez UE).

\section{Przegląd literatury w zakresie raportowania schematów podatkowych}

$\mathrm{Z}$ uwagi na to, że raportowanie schematów podatkowych jest nową regulacją, literatura i opracowania naukowe dotyczące tej materii są bardzo nieliczne.

Zagadnienie raportowania schematów podatkowych przez przedsiębiorstwa komunalne zostało podjęte przez M. Rzeszutek (2019). Autorka zwraca uwagę na fakt, że wprowadzenie raportowania schematów podatkowych w Polsce jako tzw. dobrej praktyki dla podatników przyczyni się do upowszechnienia tego rozwiązania. Zdaniem M. Rzeszutek obowiązek informacyjny doprowadzi z pewnością do aktualizacji i korekt stosowanych strategii, modeli i metod zarządzania spółkami komunalnymi. Według autorki wymogi ustawowe w zakresie raportowania transakcji powodują konieczność szczegółowej weryfikacji każdej operacji gospodarczej.

Bezpośrednią przesłanką wprowadzenia raportowania schematów podatkowych są wyniki badań dokonywanych przez specjalistów zatrudnionych przez Unię Europejską (Taxation Trends... 2019). Z przeprowadzonych badań trendów wpływów podatkowych wynika, że efektywne wpływy z tytułu podatku dochodowego od osób prawnych systematycznie spadają od 2005 r. Szczegółowe dane zaprezentowano na rys. 1 . Z przedstawionego wykresu wynika, że ustawowe i skuteczne opodatkowanie osób prawnych zmniejsza się od 2005 r., natomiast przychody przedsiębiorstw rosną powoli od 2009 r. (Kaźmierski 2018).

Pomimo że obecnie nie ma wielu pozycji literatury krajowej i zagranicznej dotyczących schematów podatkowych, warto zwrócić uwagę na kilka opracowań, które mogły mieć wpływ na implementację rozwiązań w zakresie raportowania schematów podatkowych do prawodawstwa poszczególnych krajów unijnych. O sposobach obejścia prawa podatkowego pisał P. Karwat (2002, s. 45), z kolei 
zjawisko uchylania się od podatku dochodowego i metody jego ograniczenia analizował A. Bernal (2008, s. 57).

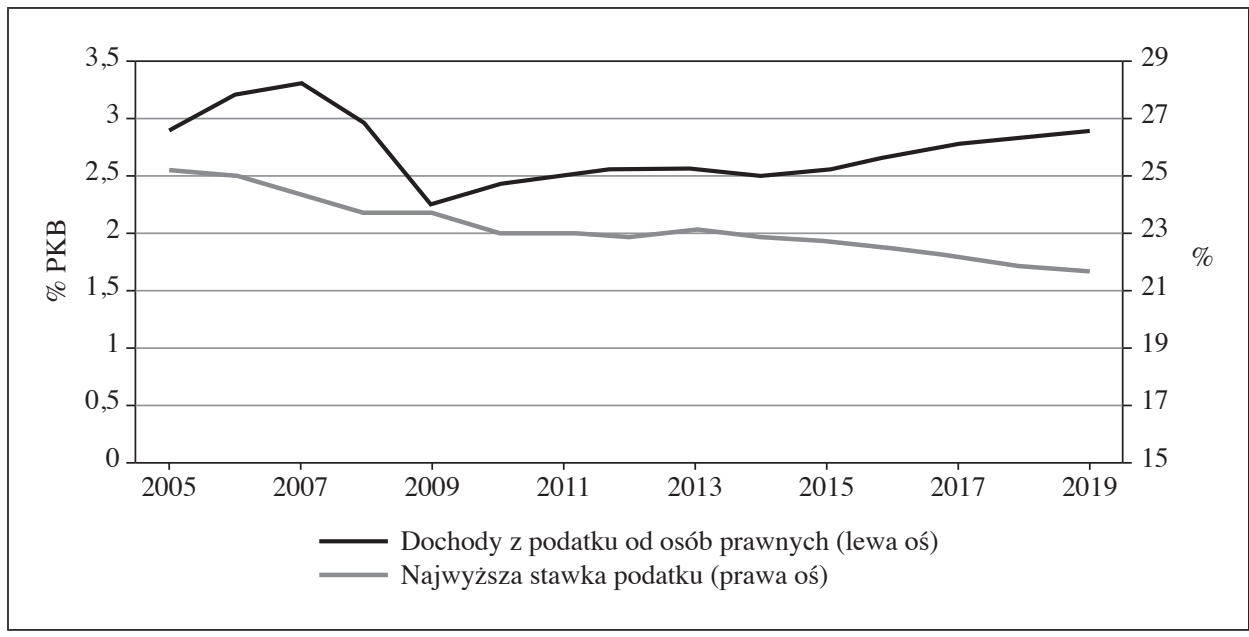

Rys. 1. Wpływy z tytułu podatku dochodowego od osób prawnych Źródło: taxation_trends_report_2019_key_messages (data dostępu: 1.05.2019).

Przegląd regulacji w zakresie raportowania schematów podatkowych, obejmujący definicje promotora, korzystającego, wspomagającego, zawierający wyjaśnienie, czym jest schemat podatkowy, określający, czy każdy schemat podatkowy podlega raportowaniu oraz na czym polega obowiązek przekazywania informacji o schemacie podatkowym, a także opisujący odpowiedzialność karną za naruszenie obowiązków w zakresie raportowania MDR, zawiera rozdział pt. „Raportowanie schematów podatkowych (MDR)" (Podatki 2019... 2019).

Autorzy różnych opracowań zwracają uwagę na istotne luki w regulacjach dotyczących raportowania schematów podatkowych i konieczność dokonania zmian (Koślicki 2019). Wątpliwości autorów budzi to, jak konkretna grupa korzystających powinna złożyć raport MDR-3, czy obowiązek ten dotyczy kwalifikowanych korzystających, czy wszystkich korzystających. W takiej sytuacji najprostsza optymalizacja podatkowa, dopuszczona nawet przez ustawy podatkowe, jak przejście rzemieślnika na ryczałt od przychodów ewidencjonowanych, czy też na kartę podatkową, może zostać uznana za schemat podatkowy, z którego zastosowania należy zdać raport MDR-3. Eksperci podatkowi zwracają uwagę, że celem wymienionych regulacji nie było wprowadzenie obowiązku raportowania schematów podatkowych przez wszystkich korzystających. Wyrażane są również poglądy, zgodnie z którymi tylko kwalifikowany korzystający jest zobligowany do raportowania schematów podatkowych. 
Istotne są rozważania dotyczące konieczności raportowania schematów podatkowych przez biura rachunkowe. Należy zwrócić uwagę, że biuro rachunkowe może występować zarówno w charakterze wspomagającego, jak i promotora. Autorzy opracowań zwracają uwagę, że promotorem może być nawet księgowa, która dokonuje rozliczeń danego klienta.

Przygotowanie scenariuszy rozwiązań podatkowych, nawet jeżeli kancelaria nie wskaże własnej rekomendacji, także może prowadzić do uznania, że podmiot działa w charakterze promotora. Stanie się tak, gdy opinia nie będzie zawierała jednoznacznej rekomendacji doradcy, ale będzie skonstruowana w sposób pozwalający na porównanie skutków podatkowych przyszłych działań, w czego konsekwencji rozsądny podmiot jest w stanie wywnioskować, jaki wariant jest rekomendowany z perspektywy podatkowej (nawet jeżeli literalnie takie wskazanie nie zostanie sprecyzowane). Zdecydowanie częściej biuro rachunkowe będzie występowało w charakterze wspomagającego (Zaniewicz 2019).

Od 1 stycznia 2019 r. podmioty świadczące usługi doradcze, w szczególności radcy prawni, adwokaci i doradcy podatkowi zostali zobowiązani do ujawniania tzw. schematów podatkowych udostępnianych podatnikom. Ustawodawca wprowadził pewne instrumenty chroniące tajemnicę zawodowo wymienionych podmiotów. Niemniej należy zwrócić uwagę na słabość mechanizmów gwarantujących zachowanie tajemnicy zawodowej przez wymienione grupy zawodowe. Budzi to wątpliwości co do zgodności przyjętych rozwiązań (Wilk 2019).

\section{Procedura raportowania schematów podatkowych i jej wdrożenie w podmiotach wybranych do badania}

\subsection{Elementy procedury raportowania schematów}

Do badania w sposób celowy wybrano trzy spółki prawa handlowego. Większościowym udziałowcem (akcjonariuszem) wszystkich spółek jest jeden podmiot dominujący z siedzibą w Gdańsku.

Zawartość wewnętrznej procedury określono w art. 861 par. 2 Ustawy z dnia 29 sierpnia 1997 r. - Ordynacja podatkowa (publikacja: Dz.U. 2019 r. poz. 900, 924, 1018, 1495, 1520, 1553, 1556, 1649, 1655, 1667, 1751, 1818, 1978, 2020 i 2200), zgodnie z którym wewnętrzna procedura obejmuje w szczególności (z uwzględnieniem charakteru, rodzaju i rozmiaru prowadzonej działalności) stosowane zasady postępowania (Wawrzonkiewicz, Wolak i Zagórski 2019):

1) określenie czynności lub działań podejmowanych w celu przeciwdziałania niewywiązywaniu się z obowiązku przekazywania informacji o schematach podatkowych, 
2) środki stosowane w celu właściwego wypełnienia obowiązku przekazywania informacji o schematach podatkowych,

3) określenie zasad przechowywania dokumentów oraz informacji,

4) określenie zasad wykonywania obowiązków obejmujących przekazywanie Szefowi Krajowej Administracji Skarbowej informacji o schematach podatkowych,

5) określenie zasad upowszechniania wśród pracowników tego podmiotu wiedzy z zakresu przepisów omawianego rozdziału,

6) określenie zasad zgłaszania przez pracowników rzeczywistych lub potencjalnych naruszeń przepisów omawianego rozdziału,

7) określenie zasad kontroli wewnętrznej lub audytu przestrzegania przepisów omawianego rozdziału oraz zasad postępowania określonych w wewnętrznej procedurze.

Wewnętrzna procedura podlega akceptacji przez członków kadry kierowniczej wyższego szczebla danego podmiotu, w tym członków zarządu lub dyrektorów posiadających wiedzę z zakresu prawa podatkowego oraz podejmujących decyzje mające wpływ na ryzyko jego nieprzestrzegania przez kontrahentów będących korzystającymi (Ustawa z dnia 29 sierpnia 1997 r. ... 2019, art. 861 par. 3).

\subsection{Praktyczne rozwiązania $w$ zakresie wdrożenia procedury raportowania schematów podatkowych}

Charakterystykę badanych podmiotów przedstawia tabela 1, natomiast opis zawartości procedury raportowania schematów podatkowych zamieszczono w tabeli 2.

Z przeprowadzonej analizy wdrożenia procedur raportowania schematów podatkowych w wybranych do badania spółkach wynika, że w pierwszej kolejności konieczne jest powołanie zespołu ds. analizy schematów podatkowych. W jego skład powinni wchodzić nie tylko przedstawiciele kierownictwa działów finansowo-księgowych (główny księgowy, dyrektor finansowy), ale również kierownicy innych działów (np. działu zaopatrzenia, działu technicznego i handlowego). Jest to istotne, ponieważ w praktyce to kierownik działu handlowego (dyrektor handlowy) będzie miał największą wiedzę dotyczącą rodzajów klientów spółki i określenia, na jakich warunkach będzie odbywała się sprzedaż. Podobnie kierownik działu zaopatrzenia będzie podejmował decyzje, od kogo i na jakich warunkach będą nabywane dany materiał, towar czy usługa. Stąd wymienieni przedstawiciele działu handlowego i zaopatrzenia muszą ściśle współpracować z działem finansowo-księgowym. Konieczny jest przepływ informacji pomiędzy wymienionymi działami po to, żeby ocenić i ograniczyć ryzyko niewykrycia występowania schematu podatkowego. 


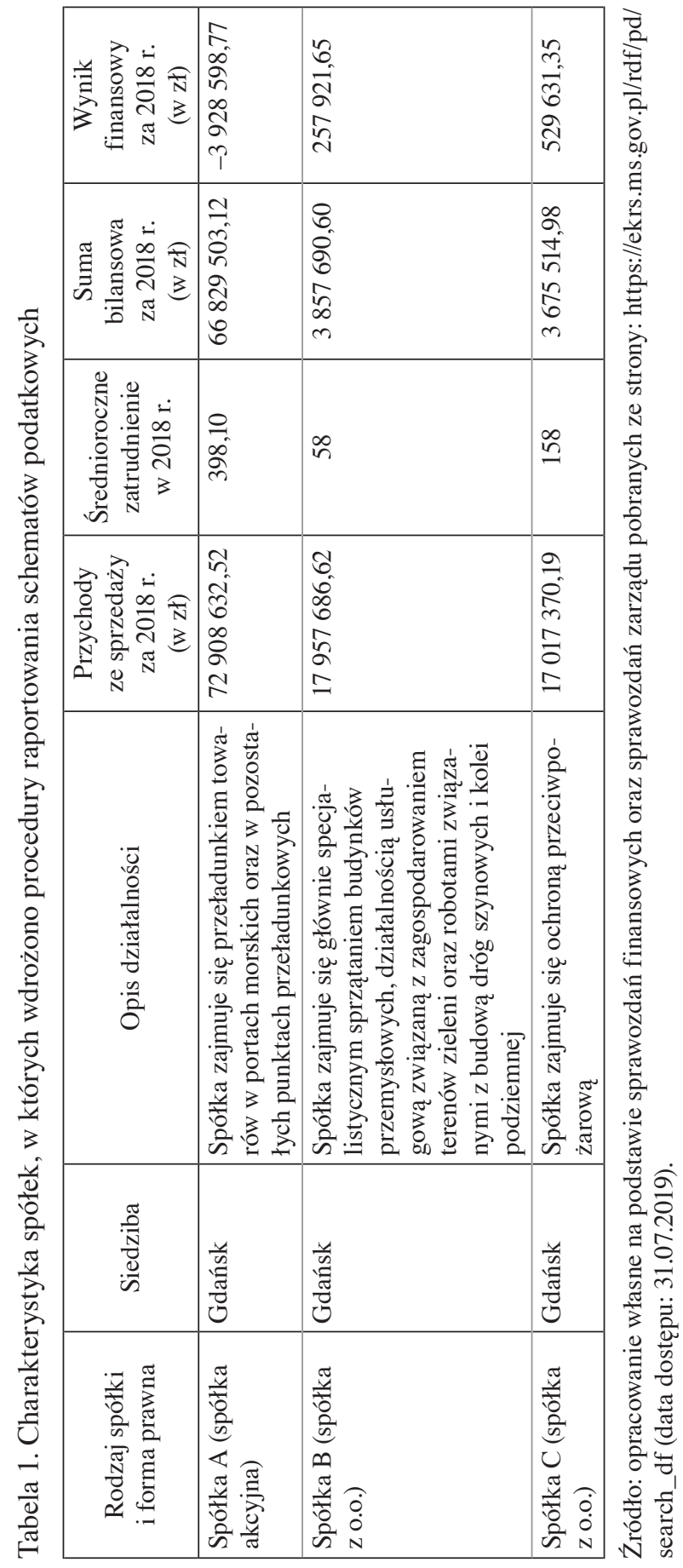




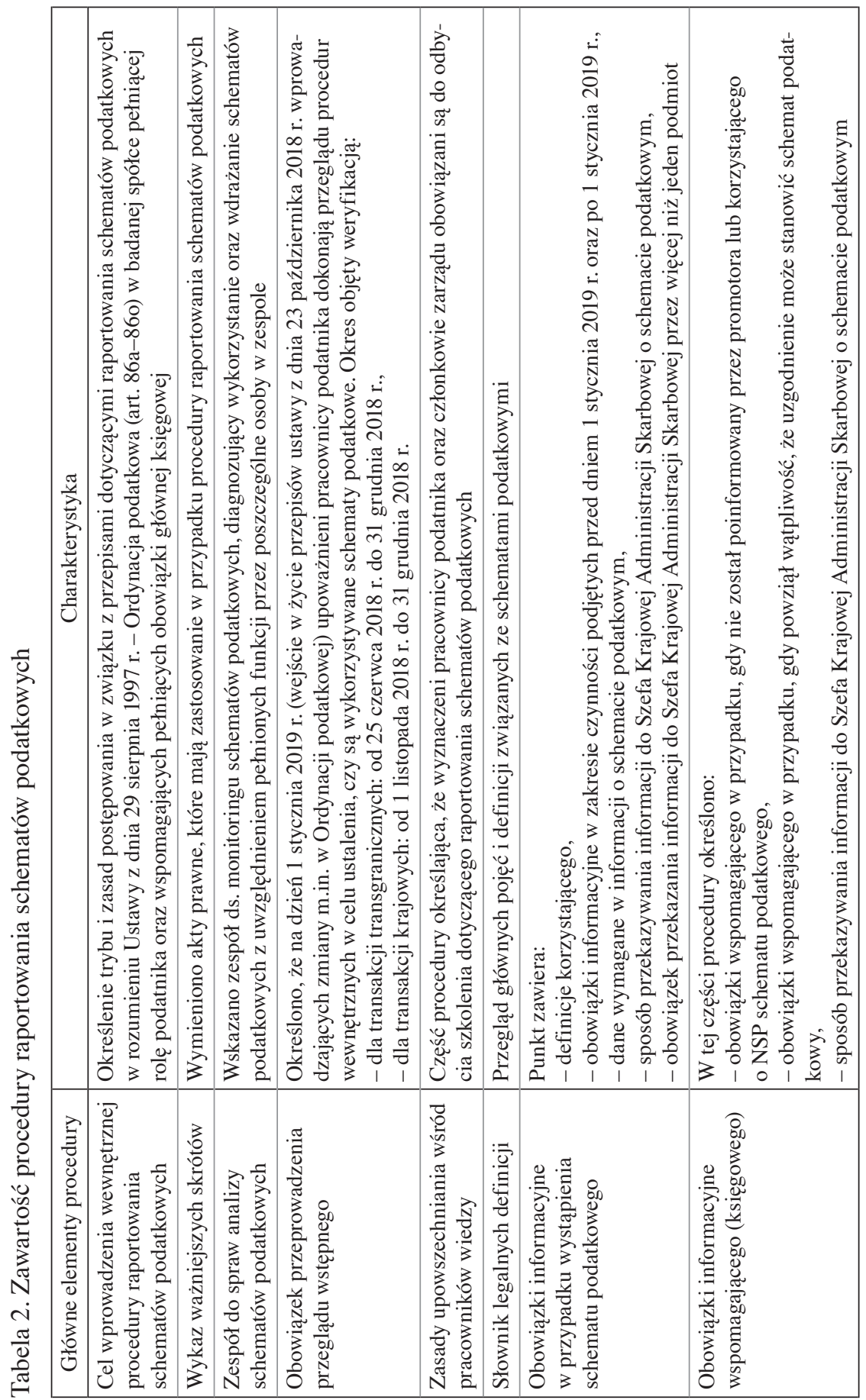




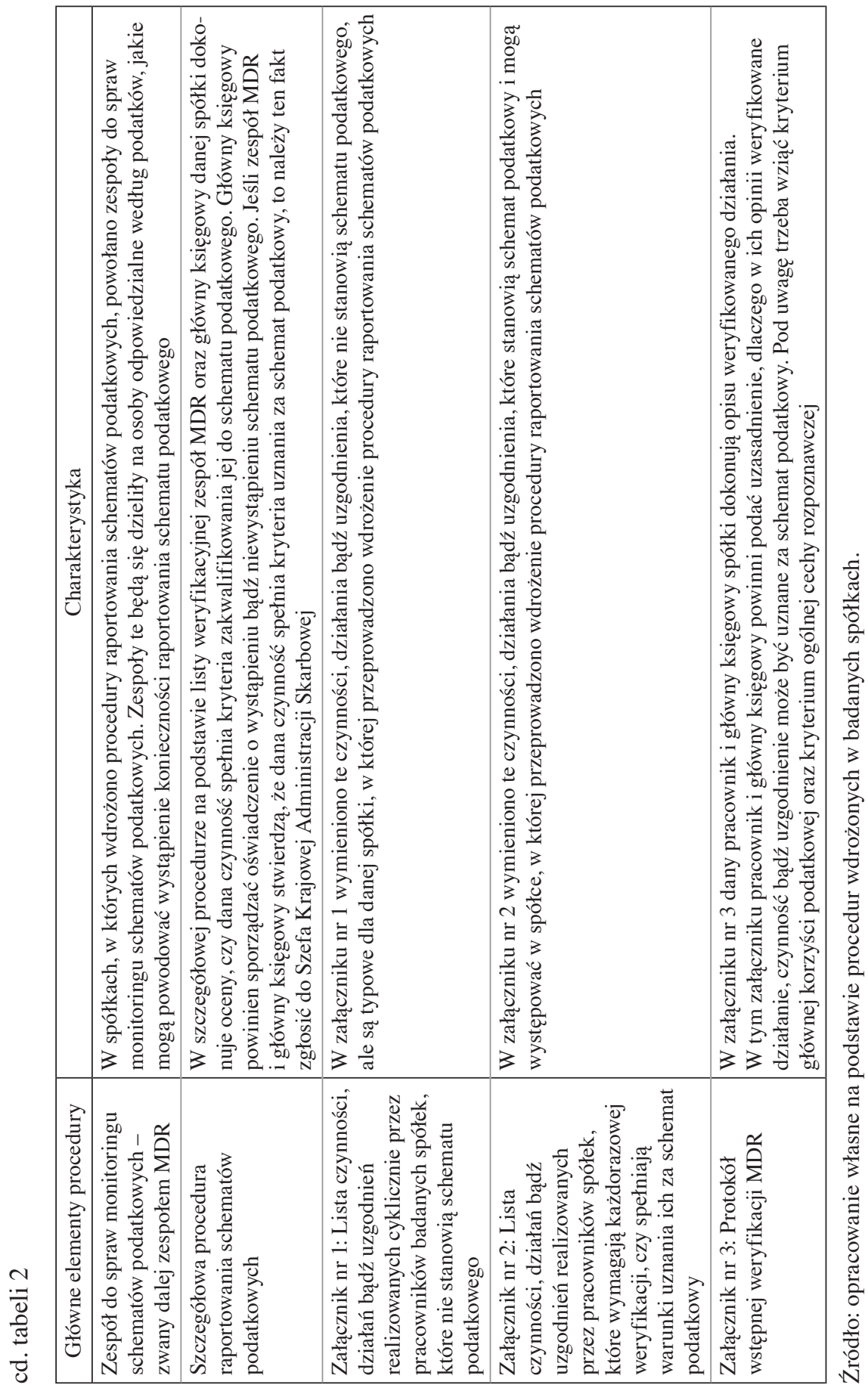


Bardzo ważne jest również przeszkolenie poszczególnych pracowników w zakresie rozpoznania konieczności raportowania schematów podatkowych. Pomocne są w tym opracowane dwa załączniki:

1) załącznik nr 1: Lista czynności, działań bądź uzgodnień realizowanych cyklicznie przez pracowników badanych spółek, które nie stanowią schematu podatkowego,

2) załącznik nr 2: Lista czynności, działań bądź uzgodnień realizowanych przez pracowników spółek, które wymagają każdorazowej weryfikacji, czy spełniają warunki uznania ich za schemat podatkowy.

Właściwie przeszkoleni pracownicy umożliwią efektywniejsze zarządzanie raportowaniem schematów podatkowych. Wiedza dotycząca tego, co jest schematem podatkowym, a co nie, pozwoli uniknąć pomyłek i błędów w rozpoznawaniu obowiązku raportowania schematu do Szefa Krajowej Administracji Skarbowej.

Kolejną istotną kwestią dotyczącą wdrożenia procedur raportowania schematów podatkowych było powołanie zespołu do spraw monitoringu schematów podatkowych (zespołu MDR). W zespole takim obowiązuje podział na osoby odpowiedzialne według rodzajów podatków, jakie mogą powodować wystąpienie konieczności raportowania schematu podatkowego. W szczególności należy wydzielić następujące rodzaje podatków: podatek od towarów i usług (VAT), podatek dochodowy od osób prawnych, podatek dochodowy od osób fizycznych, podatek od czynności cywilnoprawnych, podatek od nieruchomości oraz podatek od środków transportowych. Taki podział osób umożliwi lepsze zarządzanie obowiązkami w zakresie poszczególnych tytułów podatkowych, a przede wszystkim efektywniejsze zarządzanie schematami podatkowymi.

\section{Ocena wdrożenia procedur raportowania schematów podatkowych}

Po zakończeniu wdrożenia procedur raportowania schematów podatkowych w wybranych podmiotach postanowiono ocenić jego jakość. W tym celu zadano pytania osobom z zarządu i kierownictwa działów finansowo-księgowych wybranych spółek.

Postawiono następujące pytania:

1. Czy wdrożone procedury były pracochłonne?

2. Czy były one zrozumiałe?

3. Czy umożliwiły one efektywniejsze zarządzanie ryzykiem podatkowym?

4. Czy umożliwiły one sprawniejszy obieg dokumentów?

5. Czy procedury ograniczyły ewentualne ryzyko popełnienia błędów, nieterminowej przesyłki danych, w szczególności ryzyko wystąpienia sankcji karnej? 
6. Czy umożliwiły one wskazanie konkretnych osób odpowiedzialnych za rozliczenie poszczególnych rodzajów podatków?

7. Czy w procedurach zostało jasno zdefiniowane, co jest, a co nie jest schematem podatkowym?

Wyniki oceny wdrożenia procedur raportowania schematów podatkowych zostały zaprezentowane w tabeli 3 .

Tabela 3. Wyniki oceny wdrożenia procedur raportowania schematów podatkowych

\begin{tabular}{|l|c|c|c|}
\hline \multicolumn{1}{|c|}{ Pytanie } & Spółka A & Spółka B & Spółka C \\
\hline Czy wdrożone procedury były pracochłonne? & tak & tak & nie \\
\hline Czy wdrożone procedury były zrozumiałe? & nie & nie & nie \\
\hline $\begin{array}{l}\text { Czy wdrożone procedury umożliwiły efektywniejsze } \\
\text { zarządzanie ryzykiem podatkowym? }\end{array}$ & tak & tak & tak \\
\hline $\begin{array}{l}\text { Czy wdrożone procedury umożliwiły sprawniejszy } \\
\text { obieg dokumentów? }\end{array}$ & nie & nie & nie \\
\hline $\begin{array}{l}\text { Czy wdrożone procedury ograniczyły ewentualne } \\
\text { ryzyko popełnienia błęów, nieterminowej przesyłki } \\
\text { danych, w szczególności ograniczyły ryzyko wystą- } \\
\text { pienia sankcji karnej? }\end{array}$ & tak & nie \\
\hline $\begin{array}{l}\text { Czy wdrożone procedury umożliwiły określenie } \\
\text { konkretnych odpowiedzialnych osób za rozliczenie } \\
\text { poszczególnych rodzajów podatków? }\end{array}$ & tak & tak & tak \\
\hline $\begin{array}{l}\text { Czy we wdrożonych procedurach jasno zdefinio- } \\
\text { wano, co jest, a co nie jest schematem podatkowym? }\end{array}$ & nie & tak & tak \\
\hline
\end{tabular}

Źródło: opracowanie własne na podstawie pytań zadanych po wdrożeniu procedur raportowania schematów podatkowych.

Z przeprowadzonego badania wynika, że wdrożenie procedur raportowania schematów podatkowych miało zarówno zalety, jak i wady.

Do zalet wdrożenia procedur raportowania schematów podatkowych zaliczyć można to, że umożliwiły one efektywniejsze zarządzanie ryzykiem podatkowym. Dzięki wdrożonym procedurom wyznaczono konkretne osoby odpowiedzialne za rozliczenie poszczególnych rodzajów podatkowych. Wdrożone procedury w większości badanych spółek pozwoliły jasno zdefiniować, co jest, a co nie jest schematem podatkowym.

Do wad wdrożenia raportowania schematów podatkowych należy to, że we wszystkich badanych podmiotach zarząd i kierownicy działów finansowo-księgowych mieli problemy ze zrozumieniem terminów używanych w Ordynacji podatkowej, związanych ze schematami podatkowymi. Dodatkowo we wszystkich badanych spółkach nie odnotowano poprawy w zakresie obiegu dokumentów 
finansowo-księgowych. W większości badanych spółek wskazano również, że wdrażanie procedur było pracochłonne. Szczególnie niepokojącym sygnałem było to, że wdrożone procedury raportowania schematów podatkowych nie ograniczyły ryzyka popełnienia błędu lub wystąpienia sankcji karnej spowodowanej brakiem wysłania raportu dotyczącego schematu podatkowego.

\section{Zakończenie}

Celem artykułu była ocena wdrożenia procedur raportowania schematów podatkowych na podstawie wybranych spółek. Przeprowadzone badania udowodniły prawdziwość postawionej tezy badawczej, według której dzięki wdrożeniu procedur raportowania schematów podatkowych codzienne funkcjonowanie wybranych przedsiębiorstw jest efektywniejsze, a przede wszystkim umożliwia skuteczne zarządzanie ryzykiem podatkowym.

W artykule zaprezentowano także zalety i wady wdrożenia procedur raportowania schematów podatkowych na podstawie wdrożeń dokonanych w trzech wybranych spółkach prawa handlowego. Z przeprowadzonych badań wynika, że efektywne wdrożenie procedur raportowania schematów podatkowych umożliwia skuteczniejsze zarządzanie ryzykiem podatkowym.

Konieczne są dalsze badania, z których będzie jednoznacznie wynikać, że dzięki wdrożeniu procedur raportowania schematów podatkowych zmaleje ryzyko popełnienia błędu podczas raportowania schematów podatkowych.

\section{Literatura}

Bernal A. (2008), Zjawisko uchylania się od podatków dochodowych i metody jego ograniczania, Difin, Warszawa.

Dyrektywa Rady (UE) 2018/822 z dnia 25 maja 2018 r. zmieniająca dyrektywę 2011/16/ UE w zakresie obowiązkowej automatycznej wymiany informacji w dziedzinie opodatkowania w odniesieniu do podlegających zgłoszeniu uzgodnień transgranicznych, Dz. Urz. UE L 139, 5 czerwca $2018 \mathrm{r}$.

EU Mandatory Disclosure Rules - An Update on Local Country Implementation Status and Trends - Global Tax Alert (2019), https://www.ey.com/gl/en/services/tax/international-tax/alert--eu-mandatory-disclosure-rules---an-update-on-local-country-implementation-status-and-trends (data dostępu: 8.08.2019).

Kaczmarek M. (2019), Raportowanie schematów podatkowych (MDR) (w:) Podatki 2019 - najważniejsze zmiany VAT, CIT, PIT, Ordynacja podatkowa, Wydawnictwo Rachunkowość, Warszawa.

Karwat P. (2002), Obejście prawa podatkowego: natura zjawiska i sposoby przeciwdziatania mu, Dom Wydawczy ABC, Warszawa.

Kaźmierski A. (2018), Meritum podatki 2018, Wolters Kluwer, Warszawa. 
Koślicki K. (2019), Raportowanie schematów podatkowych z istotnq lukq, https://www. prawo.pl/podatki/mdr-1-mdr-3-kto-ma-skladac-raportowanie-schematow-podatkowych,418709.html (data dostępu: 12.06.2019).

Ladziński A., Wasiluk D. (2019), O nieprawidłowej implementacji dyrektywy 2018/822 $(M D R)$ i jej konsekwencjach, „Przegląd Podatkowy”, nr 5.

Modzelewski W. (2019), Problemy z informacjq MDR-3, https://biznes.interia.pl/szukaj/ news/witold-modzelewski-mdr-3-wzbudza-poploch,2611005? (data dostępu: 25.04.2019).

Objaśnienia podatkowe Ministerstwa Finansów z dnia 31 stycznia 2019 r. Informacje o schematach podatkowych (MDR) (2019), https://www.podatki.gov.pl/media/4417/ obja\%C5\%9Bnienia-podatkowe-mdr-z-dnia-31-01-2019.pdf.

Obowiqzek informowania Szefa KAS o schematach podatkowych (2019), „Biuletyn Informacyjny dla Służb Ekonomiczno-Finansowych", nr 5(1012).

Podatki 2019 - najważniejsze zmiany VAT, CIT, PIT, Ordynacja podatkowa (2019), Wydawnictwo Rachunkowość, Warszawa.

Rzeszutek M. (2019), Raportowanie schematów podatkowych przez przedsiębiorstwa komunalne - wybrane aspekty (w:) Tendencje rozwojowe $i$ wyzwania $w$ obszarze współczesnej rachunkowości i sprawozdawczości, red. J. Dyczkowska, Wydawnictwo Uniwersytetu Ekonomicznego we Wrocławiu, Wrocław.

Taxation Trends in the European Union: Main Results (2019), European Union, Eurostat, Directorate-General for Taxation and Customs Union.

Ustawa z dnia 26 lipca 1991 r. o podatku dochodowym od osób fizycznych (2019), tekst jednolity Dz.U. z 2019 r. poz. 1387 z późn. zm.

Ustawa z dnia 15 lutego 1992 r. o podatku dochodowym od osób prawnych (2019), tekst jednolity Dz.U. z 2019 r. poz. 865 z późn. zm.

Ustawa z dnia 29 sierpnia 1997 r. - Ordynacja podatkowa (2019), tekst jednolity Dz.U. z 2019 r. poz. 900 z późn. zm.

Wawrzonkiewicz K. (2019), Informacja o schemacie podatkowym i sposób jej przekazania do Szefa Administracji Skarbowej, Serwis Doradztwa Podatkowego, Warszawa.

Wawrzonkiewicz K., Wolak K., Zagórski M. (2019), Wzorcowa instrukcja wewnętrzna określajqca obowiqzki zwiqzane z raportowaniem schematów podatkowych przez podatników, dyrektorów finansowych i księgowych RSP-53, Instytut Studiów Podatkowych Modzelewski i Wspólnicy, Warszawa.

Wilk M. (2019), Ujawnienie schematów podatkowych a tajemnica zawodowa doradcy podatkowego, ,Przegląd Podatkowy”, nr 2.

Zalewski Ł. (2020), Transgraniczne schematy podatkowe trzeba ponownie raportować. Eksperci: To absurd, „Dziennik Gazeta Prawna”, 11.02.2020.

Zaniewicz E. (2019), Raportowanie schematów podatkowych przez biura rachunkowe, LEX/el. 2019.

\section{An Evaluation of the Implementation of Tax Scheme Reporting Procedures}

(Abstract)

Objective: The purpose of the article is to evaluate the tax scheme reporting procedures selected companies use.

Research Design \& Methods: Legal acts, the subject literature and a case study were analysed. 
Findings: The study shows that the implementation of tax scheme reporting procedures offers both advantages and disadvantages. The main advantage is that the procedures have enabled more effective tax risk management. The main drawback is that in all of the entities surveyed, the management board and heads of finance and accounting departments had problems understanding the terms used in the tax code related to tax patterns.

Implications / Recommendations: The research shows that the effective implementation of tax scheme reporting procedures enables more effective tax risk management. Further research is needed, with a view to showing that implementing tax reporting procedures mitigates the risk of making a mistake when reporting tax schemes.

Contribution: The original contribution of the article is its presentation and characterisation of the elements of the tax patterns reporting procedure.

Keywords: tax schemes, MDR, reporting procedures for tax schemes, taxation. 